\title{
HOW MILLENNIALS ARE CHANGING THE WAY WE LEARN: THE STATE OF THE ART OF ICT INTEGRATION IN EDUCATION
}

\section{(CÓMO LOS MILLENNIALS ESTÁN CAMBIANDO EL MODO DE APRENDER: ESTADO DEL ARTE DE LA INTEGRACIÓN DE LAS TIC EN EDUCACIÓN)}

\author{
Ingrid Noguera Fructuoso \\ Universitat Oberta de Catalunya, España
}

\begin{abstract}
The Millennial generation is changing the way we learn by urging educational institutions to better adapt to the needs of youth via the incorporation of educational technologies. Based on this premise, we have reviewed key reports concerning the integration of ICTs in education, i.e. with the aim of showing how education is changing, and will change to meet the needs of Millennials with ICT support. The paper concludes that most investment has simply resulted in an increase of computers and increased access to the Internet, e.g. where teachers replicate traditional approaches to education and where e-learning is viewed as being complementary to face-to-face education. Although it may seem that the use of ICTs is not currently revolutionizing learning, it is facilitating the personalization, collaboration and ubiquity of learning.
\end{abstract}

Keywords: learning, teaching and training, information and communication technologies, technological change, social change, distance-based teaching.

\section{RESUMEN}

La generación de los Millennials está cambiando la forma de aprender, promoviendo que las instituciones educativas traten de adaptarse mejor a las necesidades de los jóvenes mediante la incorporación de las tecnologías en educación. Partiendo de esta premisa, hemos revisado los informes prominentes sobre la integración de las TIC en la educación, con el objetivo de evidenciar cómo la educación está cambiando y va a cambiar, para satisfacer las necesidades de los Millennials con apoyo de las TIC. Llegamos a la conclusión que la mayor parte de las inversiones han dado lugar a un aumento de ordenadores y de acceso a Internet, con profesores que reproducen enfoques tradicionales de educación y en el que la enseñanza virtual está vista como un complemento a la formación presencial. Si bien parece que el uso de las TIC no está revolucionando el aprendizaje, se está facilitando la personalización, la colaboración y la ubicuidad del aprendizaje.

Palabras clave: aprendizaje, enseñanza y formación, tecnologías de la información y de la comunicación, cambio tecnológico, cambio social, enseñanza a distancia. 
ICT has changed our society and our citizens, with the generation of Millennials being one of the clearest examples of this change. If society changes education must change, thus, the characteristics of Millennials have significant implications on how they learn and how they need to be taught (if necessary). Digital learners are different from previous generations because they: a) are able to do several things simultaneously (multiprocessing), b) they are multiliterate (Hofstetter, 2000), c) they fuse web surfing for learning and entertainment (infotainment), d) their reasoning is based on bricolage, understood as "abilities to find something-an object, tool, document, a piece of code-and to use it to build something you deem important” (Brown, 2000, p.13), and e) they learn in situated actions.

Digital media is causing educators and students alike to shift to new ways of thinking about teaching and learning: a) from linear to hypermedia learning, b) from instruction to construction and discovery, c) from teacher-centred to learner-centred education, c) from absorbing material to learning how to navigate and how to learn, d) from school to lifelong learning, e) from one-size-fits-all to customized learning, f) from learning as torture to learning as fun, and g) from the teacher as transmitter to the teacher as facilitator (Tapscott, 1999).

This means that ICT is changing the way of learning; however, the way of teaching, the policies and curricula are still attempting to meet the challenge of preparing students for work and citizenship (Kozma, 2003). In this regard, we aim to evidence how education is changing, and will change, to meet the needs of Millennials with ICT support.

\section{ICT AVAILABILITY IN THE INFORMATION SOCIETY}

The Information Society is characterized by the incorporation of technologies to collect and distribute information among people. The use of technologies is becoming increasingly intensive at home and in everyday lives. In Europe and the USA there has been a great effort to collect and analyse data regarding electronic communication (telephone, computers, other devices, Internet connection and online activities) since 2006 to understand how citizens derive benefits from the innovative digital environment.

Looking at the data, one could say that mobile telephone ownership has increased over the years in the USA, while in Europe there has not been a progressive evolution and there was, in fact, a regression in 2012 (see Table 1). Regarding the difference among generations, it is clear that young people lead the ownership of mobile telephones. 
Table 1.

\section{Comparison of telephone ownership}

\begin{tabular}{|c|c|c|c|c|c|c|c|c|}
\hline \multirow[b]{3}{*}{ Year } & \multirow[b]{3}{*}{ Means of access } & \multicolumn{7}{|c|}{ Telephone } \\
\hline & & \multicolumn{3}{|c|}{ EU27 } & \multicolumn{4}{|c|}{ USA } \\
\hline & & -29 & $\begin{array}{c}30- \\
59\end{array}$ & $60+$ & -34 & $35-56$ & +57 & $\begin{array}{l}\text { All } \\
\text { adults } \\
(18+)\end{array}$ \\
\hline 2006 & $\begin{array}{l}\text { Only fixed telephone } \\
\text { At least one mobile } \\
\text { Only mobile access }\end{array}$ & $\begin{array}{c}1 \% \\
97 \% \\
58 \% \\
\end{array}$ & $\begin{array}{l}10 \% \\
86 \% \\
29 \% \\
\end{array}$ & $\begin{array}{c}56 \% \\
37 \% \\
6 \% \\
\end{array}$ & $\begin{array}{l}- \\
- \\
-\end{array}$ & $\begin{array}{l}- \\
- \\
-\end{array}$ & $\begin{array}{l}- \\
- \\
-\end{array}$ & $\begin{array}{c}- \\
73 \% \\
-\end{array}$ \\
\hline 2007 & $\begin{array}{l}\text { Only fixed telephone } \\
\text { At least one mobile } \\
\text { Only mobile access }\end{array}$ & $\begin{array}{c}2 \% \\
95 \% \\
54 \%\end{array}$ & $\begin{array}{l}11 \% \\
83 \% \\
33 \%\end{array}$ & $\begin{array}{c}47 \% \\
43 \% \\
9 \%\end{array}$ & $\begin{array}{l}- \\
- \\
-\end{array}$ & $\begin{array}{l}- \\
- \\
-\end{array}$ & $\begin{array}{l}- \\
- \\
-\end{array}$ & $\begin{array}{c}- \\
75 \% \\
-\end{array}$ \\
\hline 2008 & $\begin{array}{l}\text { Only fixed telephone } \\
\text { At least one mobile } \\
\text { Only mobile access }\end{array}$ & $\begin{array}{c}1 \% \\
95 \% \\
54 \% \\
\end{array}$ & $\begin{array}{l}12 \% \\
83 \% \\
32 \% \\
\end{array}$ & $\begin{array}{l}42 \% \\
50 \% \\
11 \% \\
\end{array}$ & $\begin{array}{l}- \\
- \\
-\end{array}$ & $\begin{array}{l}- \\
- \\
-\end{array}$ & $\begin{array}{l}- \\
- \\
-\end{array}$ & $\begin{array}{c}- \\
78 \% \\
-\end{array}$ \\
\hline 2009 & Mobile phone & - & - & - & $84 \%$ & - & - & $83 \%$ \\
\hline 2010 & $\begin{array}{l}\text { Both (fixed \& mobile) } \\
\text { Only fixed telephone } \\
\text { At least one mobile } \\
\text { Only mobile access }\end{array}$ & $\begin{array}{c}44 \% \\
1 \% \\
98 \% \\
53 \% \\
\end{array}$ & $\begin{array}{c}55 \% \\
5 \% \\
93 \% \\
38 \% \\
\end{array}$ & $\begin{array}{l}42 \% \\
39 \% \\
55 \% \\
13 \% \\
\end{array}$ & $\begin{array}{c}- \\
- \\
94 \% \\
41 \% \\
\end{array}$ & $\begin{array}{c}- \\
- \\
89.5 \% \\
18.5 \%\end{array}$ & $\begin{array}{c}- \\
- \\
62 \% \\
5 \% \\
\end{array}$ & $\begin{array}{c}- \\
- \\
86 \% \\
21 \%\end{array}$ \\
\hline 2011 & $\begin{array}{l}\text { Only fixed telephone } \\
\text { At least one mobile } \\
\text { Only mobile access }\end{array}$ & $\begin{array}{l}0 \% \\
98 \% \\
60 \%\end{array}$ & $\begin{array}{c}4 \% \\
93 \% \\
37 \%\end{array}$ & $\begin{array}{l}31 \% \\
63 \% \\
16 \%\end{array}$ & $\begin{array}{l}- \\
95 \% \\
-\end{array}$ & $\begin{array}{l}- \\
89 \% \\
-\end{array}$ & $\begin{array}{c}66.6 \\
\% \\
-\end{array}$ & $\begin{array}{c}- \\
85 \% \\
-\end{array}$ \\
\hline 2012 & $\begin{array}{l}\text { Only fixed telephone } \\
\text { At least one mobile } \\
\text { Only mobile access }\end{array}$ & $\begin{array}{c}1 \% \\
97 \% \\
56 \% \\
\end{array}$ & $\begin{array}{c}5 \% \\
92 \% \\
38 \% \\
\end{array}$ & $\begin{array}{l}32 \% \\
63 \% \\
14 \% \\
\end{array}$ & $\begin{array}{l}- \\
- \\
-\end{array}$ & $\begin{array}{l}- \\
- \\
-\end{array}$ & $\begin{array}{l}- \\
- \\
-\end{array}$ & $\begin{array}{c}- \\
88 \% \\
-\end{array}$ \\
\hline \multicolumn{9}{|c|}{$\begin{array}{l}\text { Source: Special Eurobarometer: E-communications Household Survey (European } \\
\text { Commission 2006-2012), Pew Internet \& American Life Project April 2006 Survey } \\
\text { (Horrigan, 2007), Pew Research Center (2010), Pew Internet \& American Life Project 2009 } \\
\text { survey (Lenhart et al., 2010), Pew Internet \& American Life Survey 2010 (Zickhur, 2011), } \\
\text { Zickhur\& Smith (2012). }\end{array}$} \\
\hline
\end{tabular}

If we look at the use of computers in Europe, there is evidence of an increase in ownership. In the USA there is a proportional relationship between the decrease in desktop ownership and the increase in laptop ownership (see Table 2). Once again, the data show that young people own more computers than older people. 
Table 2.

\begin{tabular}{|c|c|c|c|c|c|c|c|c|}
\hline & \multicolumn{8}{|c|}{ Computer } \\
\hline & \multicolumn{3}{|c|}{ EU27 } & & \multicolumn{4}{|c|}{ USA } \\
\hline Year & -29 & $\begin{array}{c}30- \\
59\end{array}$ & $60+$ & & -34 & $\begin{array}{l}35^{-} \\
56\end{array}$ & +57 & $\begin{array}{l}\text { All } \\
\text { adults } \\
(18+)\end{array}$ \\
\hline 2006 & $62 \%$ & $51 \%$ & $11 \%$ & $\begin{array}{l}\text { Desktop } \\
\text { Laptop }\end{array}$ & - & - & - & $\begin{array}{l}68 \% \\
30 \%\end{array}$ \\
\hline 2007 & $72 \%$ & $53 \%$ & $15 \%$ & $\begin{array}{l}\text { Desktop } \\
\text { Laptop }\end{array}$ & - & - & - & $\begin{array}{l}65 \% \\
37 \% \\
\end{array}$ \\
\hline 2008 & $75 \%$ & $52 \%$ & $16 \%$ & $\begin{array}{l}\text { Desktop } \\
\text { Laptop }\end{array}$ & - & - & - & $\begin{array}{l}65 \% \\
39 \%\end{array}$ \\
\hline 2009 & - & - & - & $\begin{array}{l}\text { Desktop } \\
\text { Laptop }\end{array}$ & $\begin{array}{l}53 \% \\
66 \%\end{array}$ & - & - & $\begin{array}{c}60 \% \\
46.5 \%\end{array}$ \\
\hline 2010 & $80 \%$ & $62 \%$ & $20 \%$ & $\begin{array}{l}\text { Desktop } \\
\text { Laptop }\end{array}$ & - & - & - & $\begin{array}{l}59 \% \\
52 \%\end{array}$ \\
\hline 2011 & $88 \%$ & $69 \%$ & $27 \%$ & $\begin{array}{l}\text { Desktop } \\
\text { Laptop }\end{array}$ & $\begin{array}{l}57 \% \\
70 \%\end{array}$ & $\begin{array}{l}67 \% \\
55 \%\end{array}$ & $\begin{array}{c}46.6 \\
\% \\
27.6 \\
\%\end{array}$ & $\begin{array}{c}57 \% \\
54.5 \%\end{array}$ \\
\hline 2012 & $83 \%$ & $68 \%$ & $27 \%$ & & - & - & - & - \\
\hline
\end{tabular}

Source: Special Eurobarometers: E-communications Household Survey (European Commission 2006-2012), Pew Internet \& American Life Project April 2006 Survey (Horrigan, 2007), Pew Internet \& American Life Project 2009 survey (Lenhart et al., 2010), Pew Internet \& American Life Survey 2010 (Zickhur, 2011), Zickhur\& Smith (2012).

Notes: Personal distribution of ages in US data. Personal calculation of average in US data based on different reports previously cited. In the EU in 2006 the data refer to EU25, from here it is based on EU27. EU data based on Eurobarometers reports. There was no Eurobarometer report in 2009.

Besides having mobile telephones and computers, people in the USA are increasingly adopting other devices such as game consoles, e-book readers and tablets (see Table 3). Game consoles are the most widespread while iPods and MP3 players are decreasing interest in the adult population, and tablet ownership is growing. Looking at the differences among ages, one can assume that young people have more devices. 
Table 3 .

Comparison of device ownership

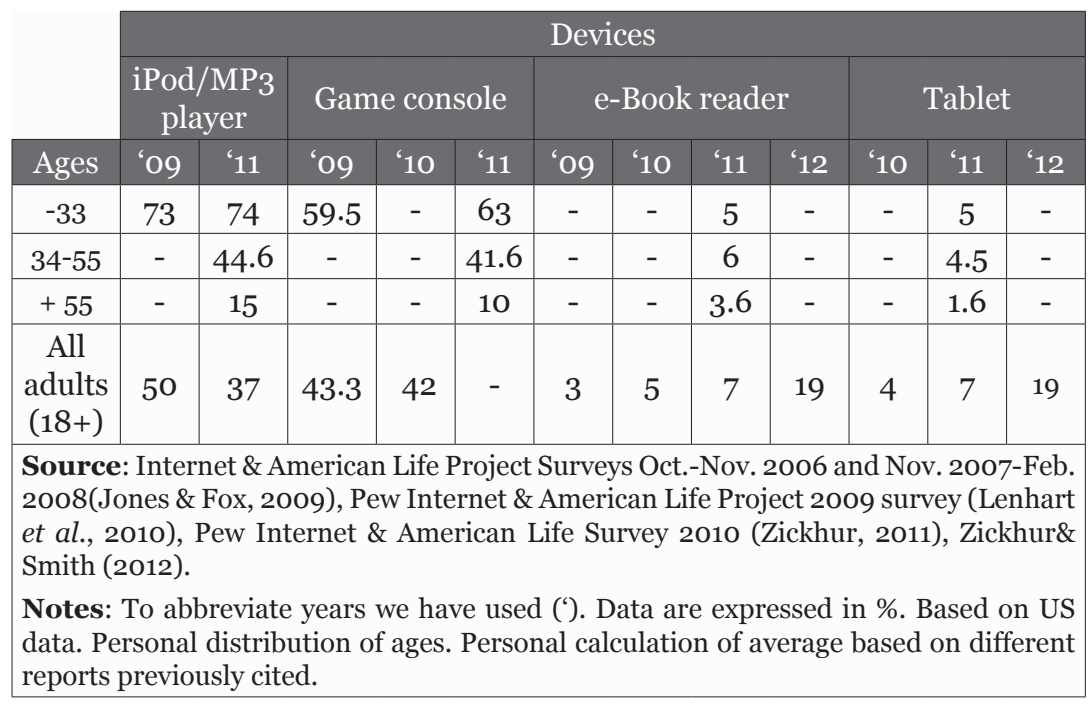

In relation to connectivity, both in Europe and the USA broadband use has risen at the same time as narrowband use has diminished (see Table 4). From 2009, studies begin to focus solely on broadband connections, which suggests that this type of access is widespread. Looking at the differences between the generations, as expected, young people are using faster Internet connections.

Table 4.

\section{Comparison of Internet connection}

\begin{tabular}{|c|c|c|c|c|c|c|c|c|c|}
\hline & \multicolumn{8}{|c|}{ Internet connection } \\
\hline & & \multicolumn{3}{|c|}{ EU27 } & & \multicolumn{4}{|c|}{ USA } \\
\hline Year & & -29 & $\begin{array}{l}30- \\
59\end{array}$ & $60+$ & & -34 & $35-56$ & +57 & $\begin{array}{c}\text { All } \\
\text { adults } \\
(18+)\end{array}$ \\
\hline 2006 & $\begin{array}{l}\text { Narrowband } \\
\text { Broadband }\end{array}$ & $\begin{array}{l}14 \% \\
23 \%\end{array}$ & $\begin{array}{l}16 \% \\
22 \%\end{array}$ & $\begin{array}{l}4 \% \\
4 \%\end{array}$ & $\begin{array}{l}\text { Narrowband } \\
\text { Broadband }\end{array}$ & $\begin{array}{l}- \\
-\end{array}$ & $\begin{array}{l}- \\
-\end{array}$ & $\begin{array}{l}- \\
-\end{array}$ & $\begin{array}{l}23 \% \\
42 \%\end{array}$ \\
\hline 2007 & $\begin{array}{l}\text { Narrowband } \\
\text { Broadband }\end{array}$ & $\begin{array}{c}8 \% \\
40 \%\end{array}$ & $\begin{array}{l}13 \% \\
26 \%\end{array}$ & $\begin{array}{l}4 \% \\
6 \%\end{array}$ & $\begin{array}{l}\text { Narrowband } \\
\text { Broadband }\end{array}$ & $\begin{array}{l}- \\
-\end{array}$ & $\begin{array}{l}- \\
-\end{array}$ & $\begin{array}{l}- \\
-\end{array}$ & $\begin{array}{l}15 \% \\
47 \%\end{array}$ \\
\hline 2008 & $\begin{array}{l}\text { Narrowband } \\
\text { Broadband }\end{array}$ & $\begin{array}{c}8 \% \\
48 \%\end{array}$ & $\begin{array}{c}9 \% \\
33 \%\end{array}$ & $\begin{array}{l}3 \% \\
8 \%\end{array}$ & $\begin{array}{l}\text { Narrowband } \\
\text { Broadband }\end{array}$ & $\begin{array}{c}68 \% \\
70.1 \%\end{array}$ & $\begin{array}{c}- \\
65.2 \%\end{array}$ & $\begin{array}{c}- \\
35.1 \%\end{array}$ & $\begin{array}{l}10 \% \\
55 \%\end{array}$ \\
\hline
\end{tabular}




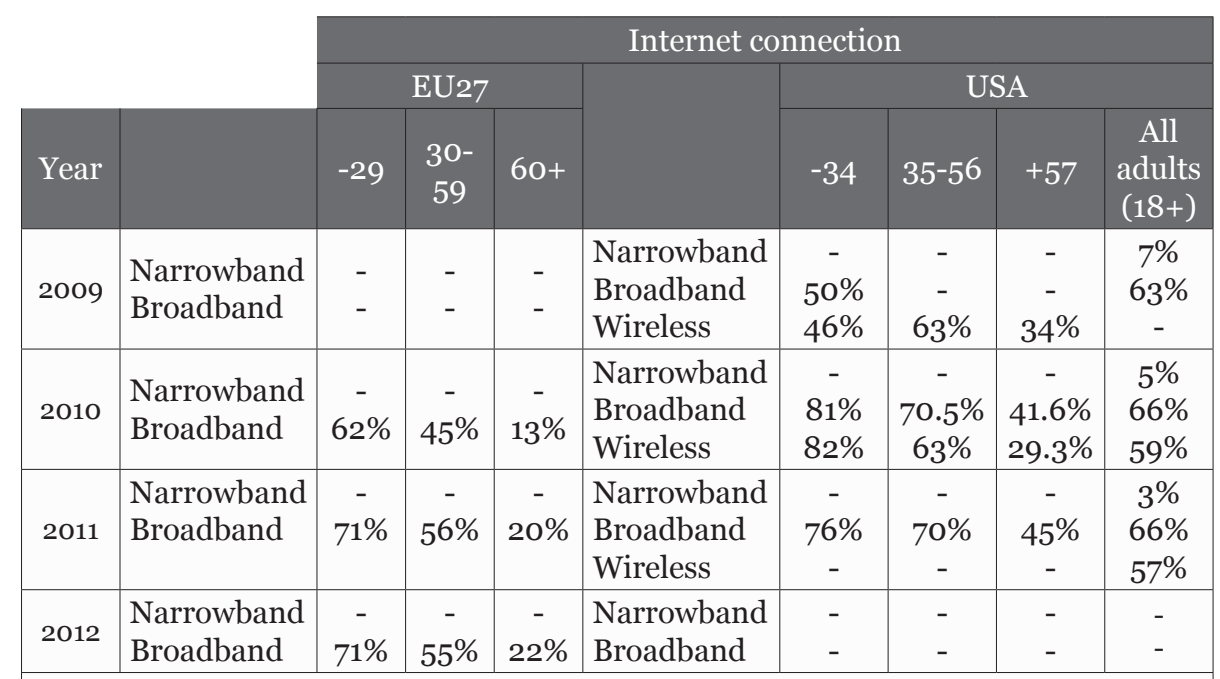

Source: Special Eurobarometers: E-communications Household Survey (European Commission 2006-2012), Pew Internet \& American Life Project Surveys Oct.-Nov. 2006 and Nov. 2007-Feb. 2008 (Jones \& Fox, 2009), Pew Internet \& American Life Project 2009 survey (Lenhart et al., 2010), Smith et al. (2011), Pew Internet \& American Life Survey 2009-2010 (Zickuhr, 2010), Zickhur \& Smith (2012).

Notes: Personal distribution of ages in US data. Personal calculation of average in US data based on different reports previously cited. In the EU in 2006 the data refer to EU25, from here it is based in EU27. EU data based on Eurobarometers reports. There was no Eurobarometer report in 2009.

Concerning the type of activities that people carry out online, one could argue that US citizens are becoming more active online year after year except in the use of social network sites, which decreased in 2011 (see Table 5). In the USA, people are more engaged in online videos, online classifieds, music and online news. Regarding blogging, it seems that the youngest people are blogging less every year while people aged 34 and older are increasingly blogging. While the Millennials' dominance of online activities is clear, older generations are also making notable gains. 
Table 5 .

Comparison of online activities

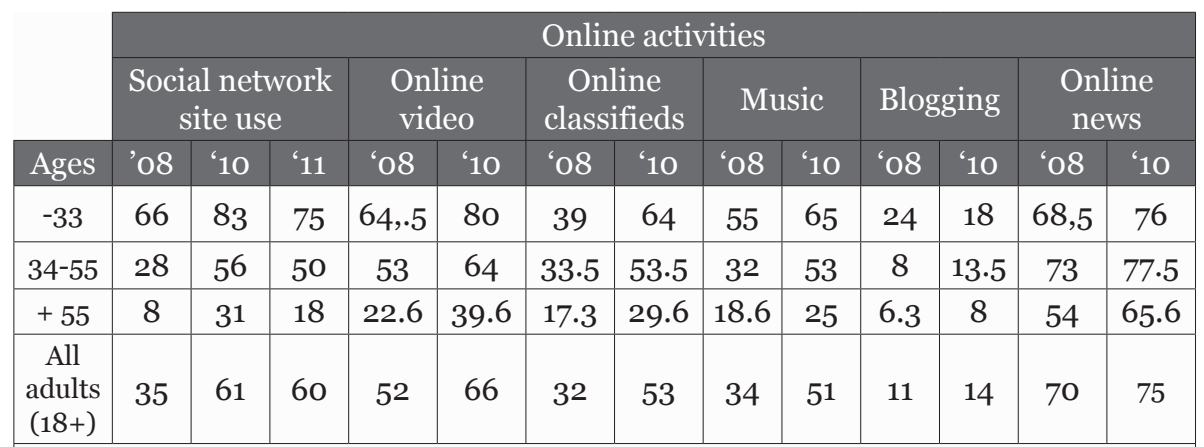

Source: Internet \& American Life Project Surveys Oct.-Nov. 2006 and Nov. 2007-Feb. 2008(Jones \& Fox, 2009), Pew Internet \& American Life Project 2009 survey (Lenhart et al., 2010), Pew Research Center (2010), Smith et al., (2011), Pew Internet \& American Life Survey 2009-2010 (Zickuhr, 2010).

Notes: To abbreviate years we have used ('). Data are expressed in \%. Based on US data. Personal distribution of ages. Personal calculation of average based on different reports previously cited.

Europeans use the Internet to send instant messages, for online networking and reading weblogs. Regarding leisure activities, European people use the Internet to listen to web radios or watch web television, to download and listen/watch/play music, films or games and to upload and share self-created content. It can be said that young people are the population who use Internet most intensively. In 2009, people used the Internet to find information and to read online, however, there was also an increase of people using the Internet to learn (Redecker et al., 2010).

The data presented and compared in this section show that in the Information Society, people are using more devices (mobile, tablets, laptops), are more connected through the Internet (broadband), are consuming Internet in a social way and are using multimedia resources. Young people are using these devices and connection in a more intensive way than other generations and are using them for learning purposes, thus, education should change to better adapt to their learning needs and expectations.

\section{YOUNG GENERATION CHARACTERISTICS AND LEARNING EXPECTATIONS}

Theyoung generation born after 1977 (Zickhur, 2011) are known as the Millennials, Net Generation, IM Generation, Gamer Generation, Digital Natives, Digital Residents or Homo Zappiens (Pedró, 2006). Millennials have been characterized as confident, liberal, optimistic, open to change, more educated than previous generations, always 
connected, steeped in digital technology and social media, and embracing multiple modes of self-expression (Pew Research Center, 2010). Their life is characterized by immediate communication and an active use of digital media that has changed their notions of communication, knowledge management, learning, and their personal and social values.

Young people are high users of technology (at home and at school); however, it does not mean that they are competent, as they need support from parents, friends and school (Eynon, 2009). To be digitally competent means having: a) instrumental knowledge and skills for digital tool and media usage, b) advanced skills and knowledge for communication and collaboration, information management, learning and problem-solving, and meaningful participation, and c) attitudes for strategic skills usage in intercultural, critical, creative, responsible and autonomous ways (Ala-Mutka, 2011). Digital competence is no longer linked to the access and use of technologies but also includes the capacity to benefit from them for life, work and learning.

Millenial learners have different expectations to previous generations concerning teaching and learning based on: a) the kind of ICT devices and services available at schools, b) the frequency of their use, c) the range of possible activities, d) the opportunities for collaborative work and networking, e) the communication skills involved, f) the degree of learning personalization, and g) the standards of digital quality (interactivity and use of multimedia resources) (Pedró, 2006). The literature (Conole et al., 2006; Redecker, 2009) indicates that, in learning processes, Millennials simultaneously and extensively use multiple types of web-based participatory media, multi-task, personalize technologies, tend towards independent learning, are constantly connected and synchronized, need immediate communication and social interaction, prefer to learn by doing and to work with things that matter, prefer to work in teams, need new skills for the digital era, are transferring practices of technology use to other aspects of their lives, and are changing working patterns.

To sum up, we could say that Millennials are using technologies intensively (and are demanding to use it in education also), are multitasking (and want to have a range of different activities in education), use multimedia resources (and expect high quality interactive materials in education), are social (and demand collaborative work and networking opportunities in education), personalize technologies to fit their needs (and assume that learning is personalized), have new skills (and expect to develop 21st century skills in the classroom), and are developing new working practices (and demand that education accepts and takes advantage of these new practices). 


\section{ICT INTEGRATION IN PRIMARY AND SECONDARY EDUCATION}

Young people are intensively using ICT for leisure, however there is a huge difference between social and academic use of ICT. The integration of ICT at the educational level is more focused on providing tools and access to the Internet than changing methodologies or moving to virtual contexts. There are many studies regarding ICT access and equipment in primary and secondary education in Europe and just a few that compare this internationally.

In primary and secondary education in OECD countries, almost all educational centres are equipped with at least one computer, have Internet connection, and the ratio of students per computer is decreasing (OECD, 2010). The USA has the smallest ratio of students per computer (3 students per computer), unlike Japan, Brazil and South Africa which have the highest ratio of students per computer (Fundación Telefónica, 2012).

In Europe, ICT is part of everyday life in education, however, there are still disparities between countries in terms of computer availability and ICT resources, and there is an increasing gap between the opportunities for using ICT at home and at schools. Less than half of European countries promote the use of online learning, although teachers' use of ICT hardware and software in the classroom is widely encouraged. Nevertheless, in several countries computers are still not readily accessible to students in the classroom (Eurydice, 2011). In fact, students use less ICT in classroom than their teachers and use more computers at home than at school. The main activity in using the Internet at school is to find information while at home they also use it to develop assignments and to share their efforts with other students (Pedró, 2011).

Research shows that ICT has a positive impact on educational performance, in fact, in e-mature schools there is a rapid increase in performance scores (Balanskat et al., 2006; European Commission, 2008b) and a positive relationship between the perceived effect of ICT on teaching and on the personalization of learning (Underwood et al., 2010). There is also a consensus (Balanskat et al., 2006; Condie \& Munro, 2007; European Commission, 2008b; Balanskat, 2009) on the positive impact of ICT on learners and learning (competences, motivation and assessment, adaptation to individual needs, support a range of learning styles-cognitive processing, independent learning, critical thinking, teamwork and student-centred learning approach), on teachers and teaching, and on communication between schools and the community (Condie \& Munro, 2007).

Based on these positive effects of ICT on education, in OECD countries, the 1:1 program has proliferated. Countries are investing in netbooks because of the low cost, light weight and the increasing availability of wireless connectivity. However, 
it is not enough to provide students with computers; teachers also need high quality infrastructure, technical support and formal training. It is clear that ICT devices do not change strategies of teaching and learning, thus, 1:1 programs depend largely on teachers (Valiente, 2010).

One of the strong findings in the current literature is that although teachers' basic ICT skills have increased, they use ICT to support existing pedagogies. Less than half of the teachers in European countries consider that they have good ICT skills and are sufficiently competent to make good didactical use of ICT, ICT is mainly used to improve the efficiency of traditional methods (Sola \& Murillo, 2011). Teacher training programs are having a limited impact on teachers' daily methodological competences in student-centred constructivist approaches (Sola \& Murillo, 2011). However, these programs, together with government interventions and issuing teachers with their own laptop computer, increase positive attitudes among teachers (Balanskat et al., 2006).

In fact, most European teachers have a positive attitude towards ICT (the most sceptical are the most experienced teachers) because of its potential to create new dynamics of classroom work, to individualize learning, to promote creativity and to motivate students. However, there is a division between teachers' practices (copying, listening, class discussion, taking notes and computer work) and students' preferences (teamwork, practical activities, working with friends, use of the computer and copying) (Sola \& Murillo, 2011). Nevertheless, the main problem in integrating ICT is the rigidity of educational systems and not the teachers.

It can be said that the integration of ICT in the USA is more extended than in Europe. Currently, US teachers bring a wide variety of digital tools into the learning process and allow mobile phones, e-readers and tablets to be used in the classroom. Half of teachers conduct online learning activities, and almost all US teachers use ICT to prepare their lessons, have different devices (laptop, smartphone, tablet, e-book) and participate in social networking. Most of them also search for new ways to learn how to effectively incorporate digital tools into the classroom. Just a few of them consider that they know more than their students about ICT, with the youngest teachers being the most confident about using ICT in education (Purcell et al., 2013).

Overall, in primary and secondary education, ICT is considered to have a positive impact, although online learning is not as widespread as in higher education. 


\section{ICT INTEGRATION IN HIGHER EDUCATION}

\section{E-learning in higher education}

Reports focused on the impact of ICT in higher education do not address the number of computers or access to the Internet but focus more on the discussion about face-to-face and virtual learning and, currently, reflect on the use of web 2.0 tools. The research has mainly been conducted in Europe (most of the studies were conducted in the UK) and the USA, with a lack of international comparisons.

Technology has had-and will continue to have-a significant impact on higher education (Glenn, 2008). There is evidence that students in online conditions perform better (if they are guided and have media to control their interactions and prompt reflection) and that blended learning is better than face-to-face learning (if it includes variation in terms of curriculum materials and instructional approach) (Means et al., 2010).

At a European level, ICT is bringing improvements to teaching methods (tending towards collaborative, problem-based and project-based learning), is transforming the role of teachers and students, is motivating students, and is fostering the internationalization of higher education through virtual mobility (European Commission, 2008b). Regarding the benefits of social computing, the literature (Ala-Mutka et al., 2009; Redecker, 2009; Redecker et al., 2010) indicates that that learning 2.0: a) facilitates access to information within the institution, b) promotes collaboration and networking, c) responds better to the changed cognitive processes and learning patterns, d) facilitates teaching learner-centred methods and redefines the roles of teachers and students, e) contributes to the personalization of learning, f) promotes independent, autonomous and self-directed learners, g) increases motivation, academic achievement, participation and new forms of expression, $\mathrm{h}$ ) facilitates inclusion, equity, lifelong learning and learner mobility, and i) enhances innovation and creativity.

Evidence shows (European Commission, 2008b; OECD, 2005; PlsRamboll Management, 2004; Punie et al., 2006) that e-learning is growing, although faceto-face learning remains central in higher education where e-learning is seen as a supplementary tool (most universities use LMS). Findings demonstrate that e-learning has not revolutionized learning and teaching; however, it is having an important impact on administrative processes.

In 2006, data showed that few adults in Europe used the Internet for formal learning activities and not many adults and students had participated in e-learning courses (although most of the students used the Internet in formal learning). Adults participating in education and using the Internet could not imagine taking 
an e-learning course and more than half of the people surveyed preferred guided learning to autodidactic methods. From those who had taken an online course, more than half were satisfied with online learning and most of them preferred to participate in online courses rather than in face-to-face courses (Punie et al., 2006).

The results from the USA demonstrate that they are a step further ahead in ICT integration and confidence in comparison to Europe. Based on surveys from the last decade regarding online higher education in the USA (Allen \& Seaman, 2013), it can be argued that the number of students enrolled in online courses is growing and academic heads are progressively including online learning in their long-term strategies (although they believe that teaching online takes more faculty time). Academic leaders are increasingly considering that students' learning outcomes in online learning are the same or superior to those in face-to-face courses, however, the faculty do not always accept the value and legitimacy of online education. In fact, the results of one study (Taylor et al., 2011) demonstrate that just a third of people (and a third of adults who have taken a class online) consider online courses as valuable as face-to-face ones, while half of the college presidents surveyed consider it equally valuable.

Most college presidents state that their institutions offer online courses (almost a third of college graduates have taken a class online) although half of them predict that 10 years from now most of their students will take classes online. Regarding the use of devices in classroom, half of the college graduates surveyed state that they have used a laptop, smartphone or tablet computer in class sometimes and almost half the college presidents say students are allowed to use these devices (Taylor $e t$ al., 2011).

However, students continue to view face-to-face interaction as the best way of teaching (Ipsos Mori, 2008; Committee of Inquiry into the Changing Learner Experience, 2009). The research conducted by Ipsos Mori (2008) shows that students can feel uncomfortable when teachers relate to them in non-hierarchical structures or less formal methods, they consider themselves to be more digitally literate than their teachers and they prefer teachers not to use technologies if they are not sufficiently competent. Furthermore, students have difficulties using social tools in education, and need teachers to use ICT effectively to improve their practical skills with ICT. Students use social networks intensively but sometimes react negatively when they are promoted by teachers. They clearly see the usefulness of some technologies for learning (i.e. WebCT, online administration, course specific information online, emailing tutors) but do not see how wikis and collaborative learning can help them to learn (Ipsos Mori, 2008). 


\section{Emerging technologies in higher education}

There has been huge interest in analysing the specific technologies emerging in higher education every year. The Horizon Report, published by the New Media Consortium, collects and summarizes emerging technologies divided into three time horizons. It began to analyse the emerging technologies in North America and progressively incorporated other regions such as Australia (2008) and Iberoamerica (2010). In the UK, since 2006, some independent research (BECTA, 2006, 2007, 2008; Sharples et al., 2012) has collected emerging technologies in a non-systematic way.

If we analyse the evolution of emerging technologies in higher education we could say that the same technologies are highlighted everywhere (see Table 6). In general, technologies are becoming more ubiquitous, social, personal, open and based on cloud computing. Game-based learning, augmented reality and semantic applications are also having a great impact. However, the main emerging technology for learning seems to be the mobile phone. In 2012, mobile apps and tablet computing were still emerging technologies in North America and Iberoamerica.

Social computing has grown faster than expected. In North America, in 2005, it was predicted that social computing was going to be present in education by 2009 . However, in 2006 it was already highlighted as an emerging technology on the horizon of one year or less. Other technologies such as virtual worlds have had a small impact on education (they were only cited in 2007-2008).

There are a few differences between countries. For example, in the UK ubiquity and games are not cited until 2007 while in North America they appeared in 2005. In Australia they are more focused on devices while in Iberoamerica the emerging technologies are those related to collaboration and social practices.

Table 6.

Comparison of emerging technologies

\begin{tabular}{|l|l|l|l|}
\hline \multicolumn{2}{|c|}{} & \multicolumn{3}{|c|}{ Emerging technologies } \\
\hline 2004 & $\begin{array}{l}\text { Learning objects, } \\
\text { scalable vector } \\
\text { graphics. }\end{array}$ & $\begin{array}{l}\text { 2-3 } \\
\text { Rapid prototyping, } \\
\text { multimodal interfaces. }\end{array}$ & $\begin{array}{l}\text { Context-aware } \\
\text { computing, knowledge } \\
\text { webs. }\end{array}$ \\
\hline 2005 & $\begin{array}{l}\text { Extended learning, } \\
\text { ubiquitous wireless. }\end{array}$ & $\begin{array}{l}\text { Intelligent searching, } \\
\text { educational gaming. }\end{array}$ & $\begin{array}{l}\text { Social networks } \\
\text { and knowledge } \\
\text { webs, context-aware } \\
\text { computing and } \\
\text { augmented reality. }\end{array}$ \\
\hline
\end{tabular}




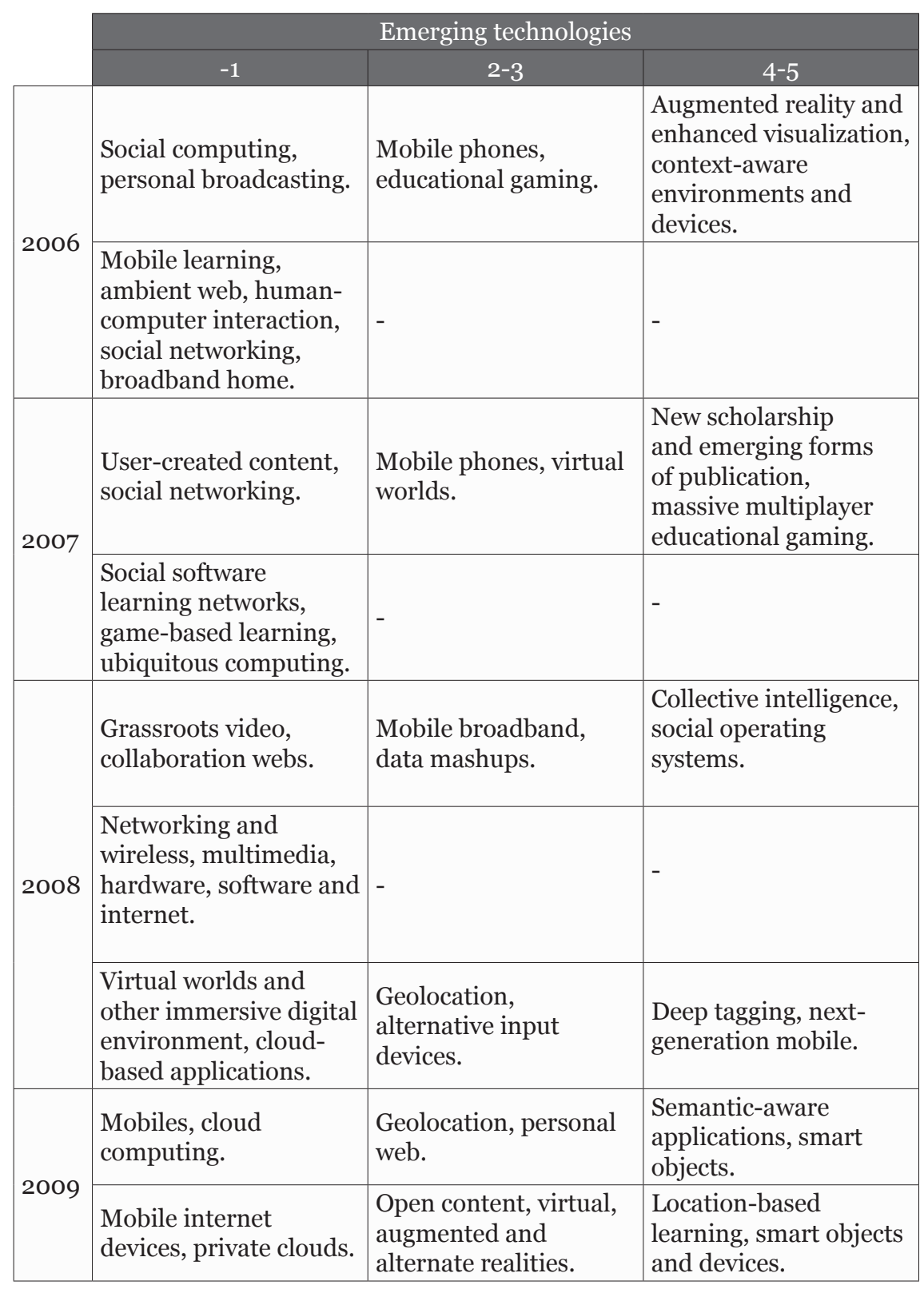


\& Goldberg, 2010), the effective pedagogical approach of the future for Millenial learners will be based on: a) ubiquity and flexibility, b) personalization, selfregulation and learner-centred, c) experimental, real life, participative and active learning, d) collaboration, interactivity, social learning and networking, e) creativity, f) reflection, g) responsibility, h) digital competence, and i) lifelong and life-wide learning.

\section{CONCLUSIONS}

Young people are leading the change in the Information Society by using technologies intensively to communicate and to learn. The characteristics of the Millennials are creating a gap between students and educational institutions. For this reason, there have been great efforts to introduce ICT into education, expecting a positive impact.

There are very few studies comparing the impact of ICT on education internationally and the prominent research is based in Europe and the USA. In the USA there is a long tradition of gathering information about ICT in education and they are better equipped and aware of the positive implications of using ICT.

ICT integration into primary and secondary education is more focused on providing tools and access to the Internet than on changing methodologies or moving to virtual contexts. In higher education the use of ICT is more widespread than in other educational levels, and is more focused on blended and e-learning practices. However, face-to-face practices remain central while e-learning is seen as a supplementary tool. Teachers tend to reproduce traditional methodologies and it could be said that technologies are not revolutionizing teaching and learning at this level.

The effective technology-enhanced practices of the future will be those seen as useful by teachers and students and will be based on flexibility, personalization, active learning, collaboration, creativity, reflection, responsibility, digital competence, lifelong and life-wide learning. 


\section{REFERENCES}

Ala-Mutka, K. (2011). Mapping Digital Competence: Towards a Conceptual Understanding. Seville: Institute for Prospective Technological Studies. Retrieved from http://ftp.jrc.es/ EURdoc/JRC67075 TN.pdf.

Ala-Mutka, K., Bacigalupo, M., Kluzer, S., Pascu, C., Punie, Y., \& Redecker, C. (2009). Learning 2.o: The impact of web 2.o innovations on education and training in Europe, Final report. Seville: Institute for Prospective Technological Studies. Retrieved from http://ftp.jrc. es/EURdoc/JRC55629.pdf.

Ala-Mutka, K., Redecker, C., Punie, Y., Ferrari, A., Cachia, R., \& Centeno, C. (2010). The future of learning: European teachers' visions report on a foresight consultation at the 2010 eTwinning conference, Seville 5-7 February. JRC Technical Notes. Retrieved from http:// ftp.jrc.es/EURdoc/JRC59775 TN.pdf

Allen, I. E., \& Seaman, J., (2013). Changing course: Ten years of tracking online education in the United States. Newburyport, MA.

Balanskat, A. (2009). Study of the impact of technology in primary schools: Synthesis Report. European Commission. Retrieved from http://insight.eun.org/ ww/en/pub/insight/minisites/steps. htm.

Balanskat, A., Blamire, R., \& Kefala, S. (2006). The ICT Impact Report: A Review of Studies of ICT Impact on Schools in Europe. European Schoolnet. Retrieved from http://insight.eun.org/ shared/data/pdf/impact study.pdf

BECTA. (2006). Emerging technologies for learning. BECTA. Retrieved from http:// dera.ioe.ac.uk/1501/1/becta 2006 emergingtechnologies vol1 report.pdf

BECTA. (2007). Emerging technologies for learning. BECTA. Retrieved from http:// dera.ioe.ac.uk/1502/2/becta 2007 emergingtechnologies vol2 report.pdf

BECTA. (2008). Emerging technologies for learning. BECTA. Retrieved from http:// www.mmiweb.org.uk/publications/ict/ emerging techo3.pdf

Brown, J. S. (2000). Growing up digitally: How the web changes work, education and the ways people learn, Change, 32(2), 10-20.

Condie, R., \& Munro, B. (2007). British Educational Communications and Technology Agency (BECTA), corp creator, The impact of ICT in schools: Landscape review. BECTA Research. Retrieved from http:// dera.ioe.ac.uk/1627/1/becta 2007 landscapeimpactreview report.pdf.

Conole, G., De Laat, M., Dillon, T., \& Darby, J. (2006). JISC LXP: Student experiences of technologies, Final report of the JISC-funded LXP project. Southampton, University of Southampton. Retrieved from www.jisc. ac.uk/elp learneroutcomes.html.

Davidson, C., \& Goldberg, D. (2010). The Future of Thinking: Learning Institutions in a Digital Age. Chicago: The John D. and Catherine T. MacArthur Foundation. Retrieved from http://goo. $\mathrm{gl} / \mathrm{jVC} 7 \mathrm{n}$.

European Commission. (2006). Special Eurobarometer 249: E-communications Household Survey. Brussels: European Commission. Retrieved from http:// ec.europa.eu/public opinion/archives/ ebs/ebs 249 en.pdf.

European Commission. (2007). Special Eurobarometer 274: E-communications Household Survey. Brussels: European Commission. Retrieved from http:// ec.europa.eu/public opinion/archives/ ebs/ebs 274 en.pdf.

European Commission. (2008a). Special Eurobarometer 293: E-communications 
Household Survey. Brussels: European Commission. Retrieved from http:// ec.europa.eu/public opinion/archives/ ebs/ebs 293 full en.pdf.

European Commission. (2008b). Commission Staff Working Document. The use of ICT to support innovation and lifelong learning for all-A report on progress, SEC (2008) 2629 final. Retrieved from http://goo.gl/OogSf.

European Commission. (2010). Special Eurobarometer 335: E-communications Household Survey. Brussels: European Commission. Retrieved from http:// ec.europa.eu/public opinion/archives/ ebs/ebs 335 en.pdf.

European Commission. (2011). Special Eurobarometer 362: E-communications Household Survey. Brussels: European Commission. Retrieved from http:// ec.europa.eu/public opinion/archives/ ebs/ebs 362 en.pdf.

European Commission. (2012). Special Eurobarometer 381: E-communications Household Survey. Brussels: European Commission. Retrieved from http:// ec.europa.eu/public opinion/archives/ ebs/ebs 381 en.pdf.

Eurydice. (2011). Key Data on Learning and Innovation through ICT at School in Europe 2011. Brussels: EACEA P9 Eurydice. Retrieved from http://eacea. ec.europa.eu/education/eurydice/ documents/key data series/12gen.pdf

Eynon, R. (2009). Mapping young people's uses of technology in their own contexts- $A$ nationally representative survey. Coventry, Becta. Retrieved from http://dera.ioe.ac.uk/1528/

Fundación Telefónica (2012). Aprender con tecnología Investigación internacional sobre modelos educativos de futuro. Madrid, Barcelona: Fundación Telefónica, Ariel. Retrieved from http:// goo.gl/Cz73H.

García, I., Peña-López, I., Johnson, L., Smith, R., Levine, A., \& Haywood, K. (2010).
Horizon Report: 2010 Iberoamerican Edition. Austin, Texas: The New Media Consortium and the Universitat Oberta de Catalunya. Retrieved from http:// www.nmc.org/pdf/2010-HorizonReport-ib.pdf.

Glenn, M. (2008). The future of higher education: How technology will shape learning. Economist Intelligence Unit, New Media Consortium. Retrieved from http://graphics.eiu.com/upload/ The\%20Future\%200f\%20Universities. pdf.

Hofstetter, F. (2000). Multimedia Literacy Textbook. New York: McGraw-Hill Education.

Horrigan, J. B. (2007). A Typology of Information and Communication Technology Users. Washington, DC, Pew Internet \& American Life Project. Retrieved from http://www.pewinternet. org/pdfs/PIP ICT Typology.pdf.

Ipsos MORI on behalf of JISC (2008). Great Expectations of ICT: How Higher Education Institutions are measuring up. London, Ipsos MORI. Retrieved from http://goo.gl/wkAfl.

Johnson, L. (2004). The 2004 Horizon Report. Austin, Texas: The New Media Consortium. Retrieved from http:// www.fdi.vt.edu/online-resources/2004Horizon-Report.pdf.

Johnson, L., Adams, S., \& Cummins, M. (2012). The NMC Horizon Report: 2012 Higher Education Edition. Austin, Texas: The New Media Consortium. Retrieved from http://www.fdi.vt.edu/ online-resources/2012-Horizon-Report. pdf.

Johnson, L., Levine, A., \& Smith, R. (2007). The 2007 Horizon Report. Austin, Texas: The New Media Consortium. Retrieved from http://www.fdi.vt.edu/onlineresources/2007-Horizon-Report.pdf.

Johnson, L., Levine, A., \& Smith, R. (2008). The 2008 Horizon Report. Austin, Texas: The New Media Consortium. Retrieved 
from http://www.fdi.vt.edu/onlineresources/2008-Horizon-Report.pdf.

Johnson, L., Levine, A., \& Smith, R. (2008). The Horizon Report: 2008 AustraliaNew Zealand Edition. Austin, Texas: The New Media Consortium. Retrieved from http://www.nmc.org/pdf/2008Horizon-Report-ANZ.pdf.

Johnson, L., Levine, A., \& Smith, R. (2009). The 2009 Horizon Report. Austin, Texas: The New Media Consortium. Retrieved from http://www.fdi.vt.edu/ online-resources/2009-Horizon-Report. pdf.

Johnson, L., Levine, A., Smith, R., Smythe, T., \& Stone, S. (2009). The Horizon Report: 2009 Australia-New Zealand Edition. Austin, Texas: The New Media Consortium. Retrieved from http:// www.nmc.org/pdf/2009-HorizonReport-ANZ-Edition.pdf.

Johnson, L., Levine, A., Smith, R., \& Stone, S. (2010). The 2010 Horizon Report. Austin, Texas: The New Media Consortium. Retrieved from http:// www.fdi.vt.edu/online-resources/2010Horizon-Report.pdf.

Johnson, L., \& Smith, R. (2005). The 2005 Horizon Report. Austin, Texas: The New Media Consortium. Retrieved from http://www.fdi.vt.edu/onlineresources/2005-Horizon-Report.pdf.

Johnson, L., \& Smith, R. (2006). The 2006 Horizon Report. Austin, Texas: The New Media Consortium. Retrieved from http://www.fdi.vt.edu/onlineresources/2006-Horizon-Report.pdf.

Johnson, L., Smith, R., Levine, A., \& Haywood, K. (2010). The 2010 Horizon Report: Australia-New Zealand Edition. Austin, Texas: The New Media Consortium. Retrieved from http://www.nmc.org/ pdf/2010-Horizon-Report-ANZ.pdf.

Johnson, L., Smith, R., Willis, H., Levine, A., \& Haywood, K. (2011). The 2011 Horizon Report. Austin, Texas: The New Media Consortium. Retrieved from http:// www.fdi.vt.edu/online-resources/2011Horizon-Report.pdf.

Jones, S., \& Fox, S. (2009). Generations Online in 2009. Washington, DC, Pew Internet \& American Life Project. Retrieved from http://www.pewinternet. org/Reports/2009/Generations-Onlinein-2009.aspx.

Kozma, R. (2003). ICT and educational change. A global phenomenon. In $\mathrm{R}$. Kozma, (Ed.). Technology, innovation, and educational change: A global perspective. Eugene, OR, International Society for Educational Technology.

Lenhart, A., Purcell, K., Smith, A., \& Zickuhr, K. (2010). Social media \& mobile internet use among teens and young adults, Pew Internet \& American Life Project, 1-51. Retrieved from http://goo.gl/GQvO3.

Means, B., Toyama, Y., Murphy, R., Bakia, M., \& Jones, K. (2010). Evaluation of evidence-based practices in online learning: A meta-analysis and review of online learning. Center for Technology in Learning, U.S. Department of Education. Retrieved from http://www. ed.gov/about/offices/list/opepd/ppss/ reports.html.

OECD. (2005). E- learning in Tertiary Education: Where Do We Stand? Paris, France: OECD Publishing. Retrieved from http://www.oecd.org/ dataoecd/27/35/35991871.pdf.

OECD. (2010). Are the New Milleninium Learners Making the Grade? Technology use and education performance in PISA. Centre for Educacional Research and Innovation.

Pedró, F. (2006). The New Millenium Learners: Challenging our Views on ICT and Learning. France, OECD. Retrieved from http://www.oecd.org/edu/nml/.

Pedró, F. (2011). Tecnología y escuela: lo que funciona y por qué. Fundación Santillana. Retrieved from http://goo. gl/U5aui. 
Pew Research Center. (2010). Millennials: A Portrait of Generation Next. Retrieved from http://goo.gl/iqIqy.

Pls Ramboll Management. (2004). Studies in the context of de e-learning initiative: virtual models of European Universities. EU Commission, DG Education \&. Culture. Retrieved from http://goo.gl/ QQoXn.

Punie, Y., \&Cabrera, M. (2005). The Future of ICT and Learning in the Knowledge Society -Report on a Joint DG JRC-. DG EAC Workshop held in Seville, 20-21 October. Seville, European Commission Directorate-General Joint Research Centre.

Punie, Y., Zinnbauer, D., \& Cabrera, M. (2006). A review of the Impact of ICT on Learning. Working paper prepared for $D G E A C$. Institute for Prospective Technological Studies (IPTS), JRC, European Commission. Retrieved from http://ipts.jrc.ec.europa.eu/ publications/pub.cfm?id=1746.

Purcell, K., Heaps, A., Buchanan, J., \& Friedrich, L. (2013). How Teachers Are Using Technology at Home and in Their Classrooms. Pew Research Center. Retrieved from http://pewinternet. org/Reports/2013/Teachers-andtechnology.

Redecker, C. (2009). Review of Learning 2.0 Practices: Study on the Impact of Web 2.0 Innovations on Education and Training in Europe, JRC Scientific and Technical Report, EUR 23664 EN. Retrieved from ftp://ftp.jrc.es/pub/ EURdoc/JRC49108.pdf.

Redecker, C., Ala-Mutka, K., \& Punie, Y. (2010). Learning 2.0-The Impact of Social Media on Learning in Europe. Seville, IPTS. Retrieved from http://ftp. jrc.es/EURdoc/JRC56958.pdf.

Redecker, C., Leis, M., Leendertse, M. Gijsbers, G., Punie, Y., Kirschner, P., Stoyanov, S., \& Hoogveld, B. (2010). The Future of Learning: New Ways to Learn
New Skills for Future Jobs. Results from an online expert consultation. Retrieved from http://ipts.jrc.ec.europa.eu/ publications/pub.cfm?id=3659.

Redecker, C., Leis, M., Leendertse, M., Punie, Y., Gijsbers, G., Kirschner, P., Stoyanov, S., \& Hoogveld, B. (2011). The Future of Learning: Preparing for Change. Seville, Spain, Institute for Prospective Technological Studies, JRC, European Commission. Retrieved from http://ftp. jrc.es/EURdoc/JRC66836.pdf.

Sharples, M., McAndrew, P., Weller, M., Ferguson, R., Fitzgerald, E., Hirst, T., Mor, Y., Gaved, M., \& Whitelock, D. (2012). Innovating Pedagogy 2012: Open University Innovation Report 1. Milton Keynes, The Open University.

Smith, A., Rainie, L., \& Zickuhr, K. (2011). College students and technology. Pew Internet Research Group. Retrieved from http://goo.gl/G1pFm.

Sola, M., \& Murillo, J. F. (Coords.). (2011). Las TIC en la Educación: Realidad y Expectativas. Informe anual 2011. Madrid: Fundación Telefónica, Ariel, Colección Fundación Telefónica.

Tapscott, D. (1999). Educating the Net Generation, Educational Leadership, 56(6).

Taylor, P., Parker, K., Lenhart, A., \& Patten, E. (2011). The Digital Revolution and Higher Education. Washington DC, Pew Research Center. Retrieved from http://www.pewsocialtrends.org/ files/2011/08/online-learning.pdf.

Underwood, J., Baguley, T., Banyard, P., Dillon, G., Farrington-Flint, L., Hayes, M., Le Geyt, G., Murphy, J., \& Selwood, I. (2010). Understanding the Impact of Technology: Learner and School level factors. Coventry, Becta. Retrieved from http://dera.ioe.ac.uk/1434/.

Valiente, O. (2010). 1-1 in Education: Current Practice, International Comparative Research Evidence and Policy Implications, OECD Education Working 
Papers, 44. Retrieved from http:// dx.doi.org/10.1787/5kmjzwflgvr2-en.

Zickuhr, K. (2010). Generations 2010. Pew Internet \& American Life Survey 20092010. Retrieved from http://goo.gl/ KSM7v.

Zickhur, K. (2011). Generations and their gadgets. Pew Internet \& American Life Survey 201O. Retrieved from http:// www.libraryworks.com/bynumbers/ pip generations and gadgets.pdf.

Zickhur, K., \& Smith, A., (2012). Digital differences. Pew Internet \& American Life Project. Pew Research Center. Retrieved from http://goo.gl/aJ4Yh.

\section{PERFIL ACADÉMICO Y PROFESIONAL DE LA AUTORA}

Ingrid Noguera Fructuoso. Licenciada en Pedagogía, Máster en Docencia Universitaria y Doctora en Pedagogía. Desarrolla su actividad docente en la Facultad de Pedagogía de la Universidad de Barcelona y su actividad investigadora en el eLearn Center de la Universitat Oberta de Cataluña. Sus intereses de investigación son el uso educativo de las TIC en la universidad y el e-learning.

E-mail: ingridnoguera@gmail.com

DIRECCIÓN DE LA AUTORA

Calle Avenir 43, $6^{\circ} 4^{\mathrm{a}}$

08021 (Barcelona)

Fechas de recepción del artículo: 20/06/2014

Fecha de aceptación del artículo: 01/09/2014

\section{Como citar este artículo:}

Noguera, I. (2015). How millennials are changing the way of learning: the state of the art of ICT integration in education. RIED. Revista Iberoamericana de Educación a Distancia, volumen 18, $\mathrm{n}^{\mathrm{0}}$ 1, pp. 45-65. 